\title{
Patterns of external insertion in global value chains: a comparative analysis between Brazil and China
}

\author{
Padrões de inserção externa nas cadeias globais de valor: \\ uma análise comparativa entre Brasil e China
}

CAROLINE GIUSTI DE ARAÚJO* ANTONIO CARLOS DIEGUES**

RESUMO: A literatura do comércio internacional tem mostrado os benefícios da fragmentação internacional da produção aos países em desenvolvimento. No entanto, há ponderações advindas da hierarquização e comando nas cadeias globais de valor. Nessa perspectiva, esse trabalho objetiva avaliar a inserção internacional brasileira e chinesa propondo um indicador de sofisticação tecnológica nas exportações $\left(\mathrm{q}_{\text {tech }}\right)$ por intensidade tecnológica para o período 2005-2015. Os resultados apontam que o acoplamento às cadeias globais de valor e a sofisticação tecnológica têm sido direcionados a agrupamentos tecnológicos que o Brasil possui vantagens comparativas reveladas estáticas enquanto a China caminha para agrupamentos tecnológicos com vantagens comparativas dinâmicas. PALAVRAS-CHAVE: Cadeias globais de valor; inserção internacional; Brasil; China.

ABSTRACT: The international trade literature has shown the benefits of the international fragmentation of production for developing countries. However, there are considerations about the hierarchy and control in Global Value Chains (GVCs). Thus, this research aims to evaluate the Brazilian and Chinese international insertion in GVCs by proposing an index about technological sophistication in exports $\left(\mathrm{q}_{\text {tech }}\right)$ by technological intensity for 2005-2015. The results pointed out that the integration in GVCs and technological sophistication have been directed towards technological clusters in which Brazil has revealed comparative advantages, while China has been moving towards technological clusters with dynamic comparative advantages.

KEYWORDS: Global Value Chains; international insertion; Brazil; China.

JEL Classification: O57; F15.

\footnotetext{
* Doutoranda em Política Científica Tecnológica, Instituto de Geociências, Universidade Estadual de Campinas, Campinas/SP, Brasil. E-mail: carolgiustiaraujo@gmail.com. Orcid: https://orcid.org/00000002-7712-1092.

* * Coordenador do Núcleo de Economia Industrial e da Tecnologia - NEIT - Instituto de Economia da Universidade Estadual de Campinas, Campinas/SP, Brasil. E-mail: acdieguesjr@gmail.com. Orcid: https://orcid.org/0000-0002-4124-666X. Submitted: 20/March/2020; Approved: 16/February/2021.
} 


\section{INTRODUCTION}

This study aims to compare the Brazilian and Chinese international insertion in Global Value Chains (GVCs) between 2005 and 2015, by proposing an indicator calculated from the domestic value-added in exports, provided by "Trade in Value Added" (TiVA) version 2018. The central hypothesis is that Brazil and China, two emerging economies, reached international insertions with qualitative disparities in terms of technological intensity. Furthermore, the paper intends to present that the insertion patterns, in addition to being influenced by exogenous conditions discussed by the international trade literature, can also be influenced by national development strategies.

GVCs can be understood according to UNCTAD (2013) as the emergence of a borderless production system that allows developing countries a "window of opportunity" to the industrialization process without internalizing the entire production chain. Participation in GVCs is a necessary, but not sufficient, condition for productive development. Thus, authors such as Taglioni and Winkler (2014) and Nonnenberg (2014) assess that the objective of developing countries in this new international division of labor must be to overcome the static relative advantages.

Thus, in this paper, a virtuous insertion in GVCs is related to local industrial development. This, in turn, implies different forms of State participation in the process of coordinating and directing industrial policies. Therefore, it presents data about participation in GVCs, the revealed comparative advantage, and the technological sophistication indicator of exports $\left(\mathrm{q}_{\text {tech }}\right)$ calculated by the domestic value-added in exports. So, it is analyzed the quality of the international insertion between Brazil and China in the period 2005-2015.

Regarding the technological sophistication indicator $\left(\mathrm{q}_{\mathrm{tech}}\right)$, it is a proposal of this study based on the $q$ indicator presented by Hermida (2016). $\mathrm{q}_{\text {tech }}$ aims to capture sophistication simultaneously from two dimensions: (i) specialization and (ii) relevance. Thus, one can analyze the integration pattern from two perspectives, bypassing the limitations present in most indicators.

The comparison between Brazil and China is stimulated by the growth of the economic complexity index (ECI $)^{2}$ of Chinese exports, which, in 2003, was equal to that of Brazil and, in 2015, was about five times higher than that of Brazil. In addition, an overview of the development strategies of both countries shows that their choices have been different over the years, and may be one of the causes of their distinct performance in international insertion.

This study is divided into four sections, in addition to this introduction. The second one presents theoretical and measurement aspects of the international fragmentation of production; the third, the methodology; the fourth, the patterns of external insertion of Brazil and China; and the fifth, the final considerations.

\footnotetext{
${ }^{1}$ The period was chosen due to the availability of updated data from the TiVA database, version 2018 .

${ }^{2}$ See Hausmann and Hidalgo et al. (2017).
} 


\section{THEORETICAL AND MEASUREMENT ASPECTS OF THE INTERNATIONAL FRAGMENTATION OF PRODUCTION}

\section{Technological catching up from the perspective of GVCs: the challenges for developing countries}

This section aims to briefly present the framework that allows constructing the analyses of the determining factors of asymmetric patterns of integration in GVCs (by China and Brazil). That is, it does not intend to characterize the extensive debate about the transformation in the techno-productive paradigm in the last quarter of the $20^{\text {th }}$ century and its relationship with the reorganization in the competitive, innovative dynamics of accumulation within companies and the National States. Such effort would transcend the objectives of this article and, given the editorial limitations of space, it would imply an impossibility of giving greater depth to the intended contributions of the article. In this context, this study regards the debate on the relationship between integration with GVCs and development.

In general, it is based on the theoretical (Lee, 2019), historical (Medeiros, 2018), and empirical (Hermida, 2016) observation that the patterns of insertion in GVCs and their resulting impacts on development must be understood from two main conditions: (a) the domestic productive structure and (b) the national capacity to formulate industrial policies that foster a virtuous integration process that is associated with the permanent structural transformation towards more virtuous activities of the current productive paradigm. Thus, in opposition to the traditional view, which suggests a supposed automatism between integration and convergence, this article seeks to point out guidelines that allow a broader understanding of the asymmetric insertion processes of Brazil and China in GVCs, which will be empirically presented in the third section.

Concerning the conditioning of the productive structure, the paper first emphasizes that the formation of GVCs must be understood based on a sense of hierarchical and asymmetric determination that derives from decisions taken by large multinational companies. In other words, productive fragmentation occurs, in most cases, in parallel with the concentration in these companies of the intangible assets that are central to the innovative, competitive, and accumulation dynamics (Gereffi, Humphrey and Sturgeon, 2005).

As a result of this movement, a tendency to redefine the capacity to add value to the stages of the production process was observed, which the literature has called the "smile curve" (Linden et al., 2009). Thus, the value generated in industrial activities would be increasingly concentrated in the initial ( $R \& D$, chain management) and end activities (marketing, finance) of the curve. As manufacturing activities would have their relative capacity to add value reduced, there would be an increasing trend towards the servitization of industrial activities - given their centrality to the dynamics of accumulation in GVCs (Butollo, 2020). In this sense, the degrees of the possibility of productive development would be increasingly associated not only and mainly with which products are manufactured domestically, but with what 
Andreoni (2020) calls "what" (product), "how" (technology), and "where" (place) companies produce. This is because technical change reshapes the nature of sectors as production activities advance and break down their limits. Accompanying this process allows for greater clarity in defining industrial policies as it promotes its reassessment before economic and technological changes.

In this perspective, economies represent a set of complex and dynamic interdependence relationships across sectors, digitalization, and technological platforms. It is worth highlighting the transversality of some enabling technologies regarding the industrial sectors and the connectivity of the productive systems in GVCs (where), which have been impacted by digital transformations. This permanent transformation in the chains, associated with the intensification of the hierarchical logic of its constitution (taking place from the advance of servitization and digitization around technological platforms), reinforce the importance of the second conditioning factor of the patterns of insertion in these chains: the national capacity to formulate industrial policies that foster a virtuous integration process.

Still, in the perspective of Andreoni (2020), this reinforcement must be understood in a context in which industrial transformations, potentialized by the diffusion of digital technology and enabling platforms, do not represent opportunities equally distributed throughout GVCs. This is because, given the competitive logic close to the "winner takes all" movements, platforms have an extremely high tendency to concentrate value.

Similarly, Lee (2019) suggests that only the vigorous and temporally persistent adoption of active industrial and technological policies can circumvent the imprisonment of undeveloped countries in stages of low value-added in GVCs. To this end, the author suggests coevolution between the construction of local technological and productive competencies and the windows of opportunities offered by changes in international technological cycles. Thus, he initially recommends the coupling with GVCs as a way to enhance learning mainly in technologically dynamic sectors (even though the initial insertion is in stages of lower value-added) and the subsequent mobilization of this learning as an instrument to circumvent leading countries' strategies to "kick away the ladder". To this end, one should foster policies for national companies and national R\&D and the consequent search for reconfiguring the pattern of insertion in the chains - unfolded in the intra-sector upgrading, by the construction of own brands, and in the inter-sector upgrading, by investment in long-cycle technologies and with persistent potential for generating value to the agents who initially dominate the paradigm.

Despite the relative consensus among development economists about the need for industrial policies as an instrument to foster virtuous insertion, Sarti and Hiratuka (2010) have reservations about the possibility to carry out these movements, given the extremely hierarchical degree of command of these GVCs, mainly regarding intangible assets. Thus, "the hierarchization that is observed at the level of companies ends up being reproduced at the level of countries" (Sarti and Hiratuka, 2010, p. 9). Furthermore, as highlighted by Gereffi, Humphrey and Sturgeon (2005), the change brought about in the international division of labor by GVCs is not disconnected 
from the national context, that is, "the history, institutions, geographical and social contexts, the evolution of rules of the game, and path dependence are important" (p. 82). Therefore, the perspective of this study, in line with Medeiros (2019), is that this context only reinforces the importance of the capacity of State action in the coordination of national strategies to foster a national innovation system (NIS) that allows the coexistence between a virtuous movement of domestic structural transformation in parallel with a less asymmetric international integration.

In general, Tang and Hussler (2011) assess the efficiency of the Chinese innovative system by indicators such as spending on $\mathrm{R} \& \mathrm{D}$, scientific publications, patents, growth of high-tech industries, development of new products, and qualification of the workforce. The authors show that national and business spending on R\&D in relation to the GDP expanded from 1998 to 2007 because of the endogenous innovative dynamism. According to Masiero and Coelho (2014), China, in the mid-2000s, constituted an internationally competitive industrial fabric, increasing competition with traditional players and defining a "new economic geography". In this sense, the report "Made in China 2025" (European Union Chamber of Commerce in China, 2017) presents the perception of the gaps in the Chinese innovative process, discussing the incorporation of the revolution proposed by industry 4.0 into Chinese strategies.

In the Brazilian case, Sarti and Hiratuka (2017) estimate that the country became the second-largest recipient of foreign direct investment (FDI) in the 2000s among the set of developing countries. However, Arend (2015) points out that foreign flows in the productive sphere had the effect of deepening national productive specialization in the direction of sectors with a low capacity to add value and characteristic of an already overcome technological paradigm. This configuration resulted in a specialized industrial structure, with a lower degree of local integration and low technological density. De Negri, in Turchi and Morais (2017), when evaluating Brazilian innovation policy, highlights that, in the past decade, a series of measures were implemented aiming at the development of innovation capacity. However, policies are excessively fragmented in terms of investments in R\&D and there is no strategic direction for investments.

\section{The evolution in international trade metrics}

The advancement in the process of fragmentation of world production has caused intermediate products and services to cross borders multiple times. Thus, there is a double count in a country's gross exports. This scenario is causing traditional trade statistics to become increasingly insufficient to measure trade flows. Therefore, new databases and metrics have emerged to assess international trade flows.

In view of the evolution of the literature on the new international trade indicators, Marcato (2018) highlights that the study of Feenstra and Hanson (1999) was the first to formulate and calculate foreign content in domestic production, consider- 
ing the direct share of imported inputs used in production. Hummels, Ishii and Yi (1999) advanced in the statistical decomposition, presenting the direct and indirect foreign content contained in exports. The authors analyzed vertical specialization (VS), which represents the foreign value added in exports, and VS1, which captures part of the vertical specialization attributed to exports of domestic intermediaries to be exported by other countries.

Daudin, Rifflart and Schweisguth (2011), in turn, tried to answer the question "Who produces for whom?". Thus, they defined the term VS1", a subset of VS1, which represents the domestic value-added in exports of intermediate goods consumed domestically by the import of final goods. Koopman, Wang and Wei (2012) presented a mathematical formulation for VS1 and made it possible to derive all existing measures in the VS approach from a unified mathematical structure. With that, the study made it possible to break down gross exports into a set of components that can be estimated independently. Figure 1 shows the breakdown of gross exports into components of domestic value-added in exports (VT), domestic content in intermediate exports that return to the country (VS1*), and foreign content (VS) and its subcomponents.

Figure 1: Gross exports decomposition method

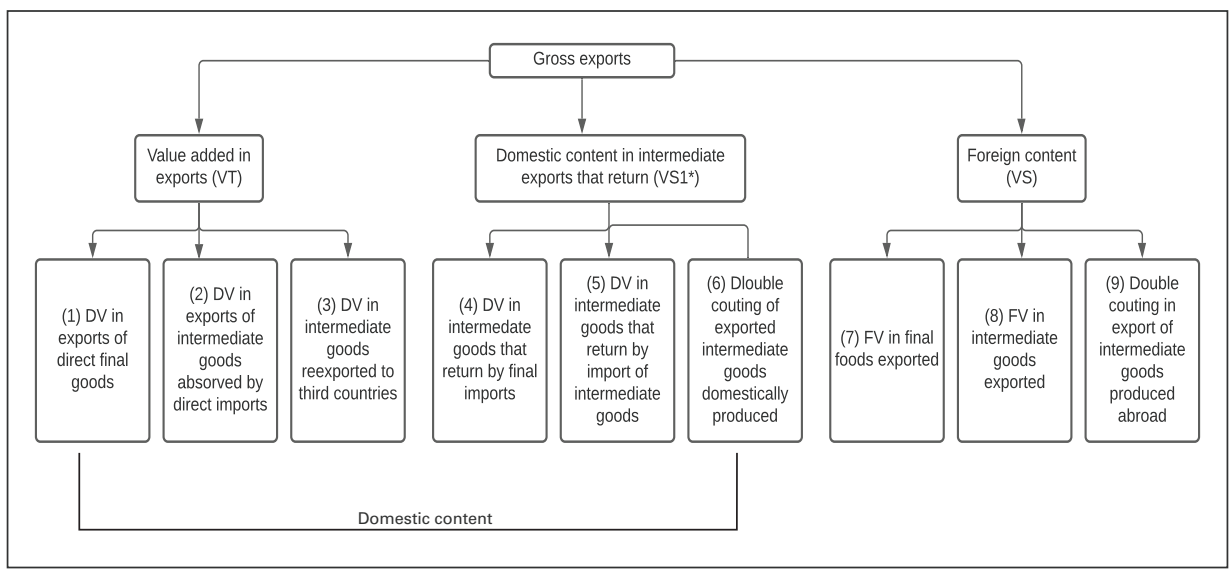

Note: DV: Domestic value added; FV: Foreign value added

Note: i) Value added in exports by country (1) + (2) + (3); ii) domestic content in a country's exports is the sum from (1) to (6); iii) VS is the sum of (7) + (8) + (9); iv) VS1 is the sum from (3) to (6); v) VS1* is (4)

Source: Koopman; Wang and Wei $(2012 ; 2014)$

By decomposing the gross value of production in terms of value-added, Koopman, Wang et al. $(2012 ; 2014)$ allowed the construction of a series of indicators that aim to consider the current configuration of the international division of production, as the methodology of this study will explore. 


\section{METHODOLOGY}

The methodological development proposed in this study uses the domestic added value in exports. For this, it is used data from the "Trade in Value Added" (TiVA database), part of the OECD.STAT database.

The indicators are derived from the 2018 version of the OECD inter-country input-output database (ICIO) and have been calculated for 65 economies (including the rest of the world) and 36 sectors (Appendix 1). This database was chosen because it presents the data in a continuous period from 2005 to 2015 for Brazil and China. In addition, the data are disaggregated in a way that makes it possible to obtain a proxy for the indicators in a global perspective and the sectoral patterns of technological grouping.

For this, the taxonomy proposed by Galindo-Rueda and Verger $(2016)^{3}$ is followed, according to the R\&D intensity. This is a taxonomy guided by previous OECD studies, and it has as novelties: i) emphasis on a measure of the intensity of $R \& D$ performance as a defining criterion; ii) coverage of the R\&D intensity analysis for service-based economic activities; iii) being based on the latest revision of the International Standard Industrial Classification (ISIC Rev.4).

The greatest relevance in using this taxonomy is due to the service sector. The ability of this classification to offer a better-detailed assessment of highly R\&Dintensive services makes it more suited to the objectives of this study in comparing two countries in GVCs. The service sector, whether upstream or downstream, represents the one with the greatest capacity to add value, according to the smile curve, reinforcing the practical and theoretical importance of being considered in the proposed aggregation.

Although the aggregation of sectors according to technological intensities allows a more detailed understanding of the movements of the productive structure from sectors with similar characteristics, several considerations must be made regarding the use of taxonomies: i) the intensification of GVCs, which causes R\&D to be related to companies located in different geographical scopes; ii) the existence of low technological intensity sectors that invest in various forms of capital, based on knowledge, and have highly qualified work teams. (Galindo-Rueda and Verger, 2016)

In this sense, it should be noted that R\&D intensity is different in developing economies, that is, there are sectors internationally classified as low technological intensity that in the local context can be classified as high technological intensity, as shown by the studies of Furtado and Carvalho (2005) for the Brazilian case. Considering these reservations, the indicators constructed from the data and descriptions of OECD (2019) are presented.

\footnotetext{
${ }^{3}$ Appendix 1 shows that a sector would promote a divergence in the classification proposed by the authors: D20T21 - Chemical and pharmaceutical products, which is aggregated in TiVA and disaggregated in the classification of the authors. The chemical sector is of medium-high technological intensity and the pharmaceutical sector is of high. Thus, to classify TiVA data, sector D20T21 was classified as high technological intensity.
} 
Technological sophistication index of exports $\left(q_{\text {tech }}\right)$ : definition, contributions to the literature, and limitations

The technological sophistication index of exports (3), one of the contributions of this study, was prepared by combining the indicator of revealed comparative advantages (1) and the market share (2), using the statistics of the domestic value-added, to measure the relative importance of a technological intensity for Brazil and China, weighted by the importance of the country in this group compared to the world.

$$
{ }_{V C R}=\frac{E X G R_{D V A}:}{E X G R_{D V A}}
$$

where: refers to the domestic value-added in gross exports; $\mathrm{t}=$ technological intensities; $\mathrm{e}=$ all sectors of the economy ${ }^{4} ; w=$ world; $c=$ Brazil or China.

$$
M S_{a}=\frac{E X G R_{D V A_{a}}}{\operatorname{EXGR}_{D V A_{w}}}
$$

where: is the domestic value-added in exports from country $c$ at technological intensity $t$; $E X G R_{D_{V A} A_{W T}}$ is the domestic value added in exports from the world $w$ at technological intensity $t$.

$$
q_{\text {wech }}=\frac{\frac{E X G R_{D V A_{i}^{\prime}}}{E X R_{D V A_{i}^{\prime}}} \frac{E X G R_{D V A_{i}^{i}}}{E X G R_{D V A_{i}^{\prime}}}}{\frac{E X G R_{D V A_{i}^{\prime}}}{E X G R_{D V A_{v}^{i}}}}
$$

where: $w=$ world; $c=$ Brazil or China; $t=$ technological intensity; $e=$ all sectors; $s=e-t$.

The nominator of $\boldsymbol{q}_{\text {tech }}$ signals structural aspects of the country's position in the assessed technological intensity. Thus, if $q_{\text {tech }}>0$, the domestic value-added in exports in the evaluated technology is higher than in other national sectors compared to the world, that is, there is a specialization of the country in that technology. Therefore, changes in signs indicate changes in the specialization.

However, it is understood that, in terms of GVCs, specialization may not represent sufficient dynamics to assess a country's integration. Hence, the index also signals the relative importance of the country's positioning considering the relevance of the economy in the world (market share). Thus, when $q_{\text {tech }}>|1|$, the relative importance of the analyzed country in technology compared to the world is greater than the relative importance of all sectors of this economy compared to the world. In this case, the technological intensity evaluated is relevant in relation to the size of the export basket.

To summarize the analysis and clarify the recomposition of technological intensities for the countries from 2005 to 2015 , Figure 2 shows an explanatory table identifying the relationship of specialization and relevance in the quadrants. First,

\footnotetext{
${ }^{4}$ That is, all industrial sectors, agriculture, mining, and services.
} 
it is important to highlight the meaning of the analysis, that is: whether $q_{\text {tech }}>|1|$ the country is relevant in the assessed technological intensity; whether $q_{\text {tech }}>0$ the country is specialized in the assessed technological intensity.

The identification of the quadrants is presented in the discussion using the abbreviations A1, A2, A3, and A4. The most important movement that a country can make is the transition from quadrant A3 to A1. The analysis by technological intensity allows understanding the movement of the sectors and the technological dynamics.

Figure 2: Grouping of $q_{\text {tech }}$ according to specialization and relevance

\begin{tabular}{|c|c|c|}
\hline 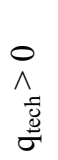 & $\begin{array}{c}\text { A2 } \\
\text { Specialized and } \\
\text { not very relevant }\end{array}$ & $\begin{array}{l}\text { Specialized and } \\
\text { relevant }\end{array}$ \\
\hline \multirow[t]{2}{*}{ 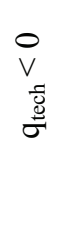 } & $\begin{array}{c}\text { Non-specialized and } \\
\text { not very relevant } \\
\text { A3 }\end{array}$ & $\begin{array}{l}\text { Non-specialized and } \\
\text { relevant } \\
\end{array}$ \\
\hline & $\mathrm{q}_{\text {tech }}<|1|$ & $\mathrm{q}_{\text {tech }}>|1|$ \\
\hline
\end{tabular}

Source: Authors' elaboration.

The analysis of Figure 2 in a comparative perspective of Brazil and China in 2005 and 2015 allows one to clarify the recomposition of sectors and technological intensities over the years, illustrating the process.

In addition, it is needed to understand the contributions of the index in theoretical background. The literature provides numerous examples of authors who measured technological sophistication by the analysis of the exported product, making it possible to enumerate some efforts: Lall, Weiss and Zhang (2006) evaluated exports by product and weighed them by the level of per capita income in exporting countries, evaluating fragmentation of production (by combining high technological and low technological sophistication), the inertia of location, and the competitiveness of countries by exports, bringing relationships between the structure of sophistication, exports, and income level. The authors present a limitation in the consideration that high sophistication (located in developed countries) would be equivalent to technological depth.

Hausmann, Hwang and Rodrik (2006) calculated a weighted average of GDP per capita of the countries that export a certain product, reflecting the comparative advantage. For each product, an index "income/level of productivity" was generated - called PRODY. Using the weighted average of PRODY, the EXPY for the country was calculated, weighting the value exported by the country of the product over the total exported of the product. (Reflects the level of productivity associated with the country's specialization pattern.) It is understood that a country with higher qualification will be able to produce goods with higher productivity 
("sophistication"). From a dynamic perspective, the specialization of an economy in the production of a product with a higher level of productivity can generate economic growth. Rodrik (2006), using these indexes applied to the Chinese case, assessed that the country presented a sophistication six times greater than expected by its income level per capita in 1992 .

Saviotti et al. (1982) used the hedonic price, in which a product is considered as a package of characteristics, and its quality increases as they increase. The index was weighted by the characteristics of the products to capture technical changes. In addition, they calculated a technological sophistication index (TSI) and, by dividing the TSI of a product by the average TSI of products that are substitutes, they obtained a relative technical sophistication index (RTSI). They also created a technical change index (TCI) - dynamic from a time perspective -, calculated by the rate of quality contribution to prices in the current year over the base year. The study has as limitations the hypothesis of the homogeneity of the product and the way of determining the relative weight of the individual characteristics.

Hausmann and Hidalgo (2017) proposed the complexity index, measured by the diversity of knowledge that a country produces, expressed in its productive diversity, and by ubiquity, that is, the number of countries that manufacture a product. Complex products will be those that have a great diversity of knowledge and are less ubiquitous. The final indicator is composed of the average ubiquity and diversity of products that a country exports iteratively corrected, relativized by the weight of each country's exports by calculating the revealed comparative advantage. Furthermore, one can calculate the complexity of the product considering the same methodology and analyze that a country tends to diversify its exports into products whose incorporated knowledge is similar to those it already produces. As a result, connected product spaces imply greater economic complexity, and more central products are more complex, with greater capacity to have competencies for the production of others.

Hummels and Klenow (2005) calculated the extensive margin to compare the prices of exports to a country $\mathrm{j}$ in relation to a reference country $\mathrm{k}$, considering the size of each exporter's set of goods (export diversification); and the intensive margin to compare nominal exports of $\mathrm{j}$ and $\mathrm{k}$ in a common set of goods (quantity), decomposing the intensive margin into a price and quantity index. The price index is used to signal differences in the quality of exports, that is, if an exporter sells a large volume of products at a higher price, it is assumed that it produces goods with higher quality. With these indexes, the authors showed that rich countries export a wide variety of products with modestly higher prices.

Schott (2004) calculated the unit value of the import of a product $\mathrm{p}$ from a country $\mathrm{c}$ by the USA. There is heterogeneity in the unit value in relation to the same products imported from different countries by the USA. This heterogeneity was associated with the GDP per capita, factor endowment, and production techniques of exporting countries. According to the author, there is no specialization oriented by endowments among products, but there is a positive relationship among the unit value of the product, the capital intensity, and skills and productive techniques. 
Thus, high-wage countries use their endowment to add features or quality to their product varieties.

Finally, Hermida (2016) proposes a technological sophistication index based on technological standards: $q_{u}=\frac{D V 2-D V 1}{D V}$, in which DV2 is the domestic value-added exported by country $s$ at time $t$ in medium and high technology sectors; DV1 is a domestic value-added exported by country s at time $t$ in primary sectors; and $D V_{\text {total }}$ is the total domestic value-added by country $s$ in its own exports. The index more accurately assesses external competitiveness and the pattern of trade specialization in the context of fragmentation of production and it is distinct from the others because of using data on domestic value-added in exports.

Thereby, $q_{\text {tech }}$ aims to overcome three limitations found in the literature, as indexes are mostly built from the gross value of exports, not capturing movements in terms of domestic value-added even in the context of international fragmentation of production. Therefore, $q_{\text {tech }}$ captures a larger share of the worldwide reorganization of production and, even though it fails to overcome the gap between value creation and capture, it softens the territorial aspect by not including the double-counting of trade flows.

In addition, the indexes built from the product perspective do not capture aspects related to the production process. That is, despite presenting wide analytical possibilities, they are restricted to the "what" and not "how" something was produced. Considering that similar products can be produced by very different processes, with wide divergences in the embedded technology, the assessment of technological standards represents more comprehensive aspects of the construction of knowledge concerning the product level. Another advantage of the index refers to the updated technological aggregation, which allows considering the service sector, according to its technological dynamics, that is, considering its R\&D intensity.

Finally, it is relevant to highlight the ability of the index to evaluate two movements: relevance and specialization, which refer to its dynamic perspective. Thus, when weighing the index by the weight of the national export structure compared to world trade, one can evaluate not only the domestic gains of technological recomposition, but how much this movement has representativeness in compared to the world, attributing greater analytical robustness to the index proposed in Hermida (2016).

However, the main limitation of the index is that it is built based on sectoral logic. This represents obstacles to a systemic discussion that considers transversal aspects arising from the new technologies, especially those related to digitization, highly pervasive. 


\section{PATTERNS OF EXTERNAL INSERTION IN A COMPARATIVE PERSPECTIVE: BRAZIL AND CHINA - 2005 AND 2015}

\section{International trade data overview}

Based on the international framework for spreading production and its ability to promote an opportunity for developing countries to foster industrialization in other ways besides the import substitution process, it is characterized by the Brazilian and Chinese insertion into technological intensity. For this, the changes observed among 2000, 2005, and 2015 in a set of indexes are presented in Table 1.

Table 1: International repositioning of Brazil and China by the new international trade metrics* (\%)

\begin{tabular}{|c|c|c|c|c|c|c|c|}
\hline & \multirow{2}{*}{\multicolumn{2}{|c|}{2005}} & \multirow{2}{*}{\multicolumn{2}{|c|}{2010}} & \multirow{2}{*}{\multicolumn{2}{|c|}{2015}} \\
\hline & & & & & & & \\
\hline & & Brazil & China & Brazil & China & Brazil & China \\
\hline \multirow{6}{*}{$\begin{array}{l}\text { Forward participation } \\
\text { proxy }\end{array}$} & $\mathrm{L}$ & $2.63 \%$ & $1.55 \%$ & $0.49 \%$ & $1.69 \%$ & $0.30 \%$ & $1.90 \%$ \\
\hline & $M L$ & $4.76 \%$ & $2.88 \%$ & $0.92 \%$ & $2.90 \%$ & $0.54 \%$ & $3.28 \%$ \\
\hline & $\mathrm{M}$ & $3.51 \%$ & $1.67 \%$ & $0.86 \%$ & $1.73 \%$ & $0.37 \%$ & $1.93 \%$ \\
\hline & $\mathrm{MH}$ & $4.89 \%$ & $4.18 \%$ & $0.97 \%$ & $4.48 \%$ & $0.51 \%$ & $5.41 \%$ \\
\hline & $\mathrm{H}$ & $2.42 \%$ & $5.18 \%$ & $0.50 \%$ & $5.07 \%$ & $0.26 \%$ & $4.62 \%$ \\
\hline & $\mathrm{T}$ & $18.23 \%$ & $15.45 \%$ & $3.74 \%$ & $15.86 \%$ & $1.98 \%$ & $17.15 \%$ \\
\hline \multirow{6}{*}{$\begin{array}{l}\text { Backwards } \\
\text { participation proxy }\end{array}$} & $\mathrm{L}$ & $1.33 \%$ & $1.13 \%$ & $0.24 \%$ & $0.65 \%$ & $0.29 \%$ & $0.63 \%$ \\
\hline & $M L$ & $3.49 \%$ & $4.69 \%$ & $0.62 \%$ & $3.25 \%$ & $0.47 \%$ & $2.62 \%$ \\
\hline & $\mathrm{M}$ & $1.77 \%$ & $3.17 \%$ & $0.22 \%$ & $2.77 \%$ & $0.19 \%$ & $2.41 \%$ \\
\hline & $\mathrm{MH}$ & $2.25 \%$ & $4.71 \%$ & $0.29 \%$ & $4.84 \%$ & $0.24 \%$ & $4.02 \%$ \\
\hline & $\mathrm{H}$ & $1.24 \%$ & $12.66 \%$ & $0.13 \%$ & $9.62 \%$ & $0.08 \%$ & $7.69 \%$ \\
\hline & $\mathrm{T}$ & $10.08 \%$ & $26.36 \%$ & $1.51 \%$ & $21.12 \%$ & $1.27 \%$ & $17.37 \%$ \\
\hline \multirow{6}{*}{$\begin{array}{l}\text { Participation in } \\
\text { global value chains }\end{array}$} & $\mathrm{L}$ & $3.96 \%$ & $2.68 \%$ & $0.73 \%$ & $2.33 \%$ & $0.59 \%$ & $2.53 \%$ \\
\hline & $M L$ & $8.25 \%$ & $7.57 \%$ & $1.54 \%$ & $6.15 \%$ & $1.01 \%$ & $5.90 \%$ \\
\hline & $\mathrm{M}$ & $5.28 \%$ & $4.84 \%$ & $1.08 \%$ & $4.49 \%$ & $0.56 \%$ & $4.34 \%$ \\
\hline & $\mathrm{MH}$ & $7.15 \%$ & $8.89 \%$ & $1.27 \%$ & $9.33 \%$ & $0.75 \%$ & $9.44 \%$ \\
\hline & $\mathrm{H}$ & $3.67 \%$ & $17.84 \%$ & $0.62 \%$ & $14.68 \%$ & $0.34 \%$ & $12.31 \%$ \\
\hline & $\mathrm{T}$ & $28.31 \%$ & $41.81 \%$ & $5.25 \%$ & $36.98 \%$ & $3.25 \%$ & $34.51 \%$ \\
\hline \multirow{5}{*}{$\begin{array}{l}\text { Comparative } \\
\text { advantage }\end{array}$} & $\mathrm{L}$ & 0.80 & 0.41 & 0.96 & 0.37 & 1.25 & 038 \\
\hline & $M L$ & 1.42 & 1.08 & 1.57 & 0.87 & 1.42 & 0.93 \\
\hline & $\mathrm{M}$ & 1.37 & 1.58 & 0.97 & 1.54 & 1.09 & 1.73 \\
\hline & $\mathrm{MH}$ & 0.90 & 0.97 & 0.69 & 1.27 & 0.56 & 1.18 \\
\hline & $\mathrm{H}$ & 0.52 & 1.80 & 0.33 & 1.91 & 0.28 & 1.69 \\
\hline \multirow{5}{*}{$\begin{array}{l}\text { Breakdown of gross } \\
\text { exports }\end{array}$} & $\mathrm{L}$ & $23.39 \%$ & $10.36 \%$ & $27.08 \%$ & $9.19 \%$ & $35.91 \%$ & $10.16 \%$ \\
\hline & $M L$ & $37.92 \%$ & $26.28 \%$ & $45.02 \%$ & $23.03 \%$ & $36.52 \%$ & $22.39 \%$ \\
\hline & $\mathrm{M}$ & $13.43 \%$ & $14.12 \%$ & $9.81 \%$ & $14.34 \%$ & $11.15 \%$ & $16.27 \%$ \\
\hline & $\mathrm{MH}$ & $17.35 \%$ & $17.84 \%$ & $13.00 \%$ & $22.62 \%$ & $12.01 \%$ & $23.29 \%$ \\
\hline & $\mathrm{H}$ & $7.90 \%$ & $31.40 \%$ & $5.09 \%$ & $30.81 \%$ & $4.41 \%$ & $27.89 \%$ \\
\hline \multirow{5}{*}{$\begin{array}{c}\text { Domestic value } \\
\text { added in exports } \\
\text { compared to gross } \\
\text { exports }\end{array}$} & $\mathrm{L}$ & $21.87 \%$ & $9.23 \%$ & $25.51 \%$ & $8.55 \%$ & $32.93 \%$ & $9.53 \%$ \\
\hline & $M L$ & $33.94 \%$ & $21.59 \%$ & $40.89 \%$ & $19.78 \%$ & $31.66 \%$ & $19.77 \%$ \\
\hline & $\mathrm{M}$ & $11.40 \%$ & $10.96 \%$ & $8.32 \%$ & $11.57 \%$ & $9.22 \%$ & $13.86 \%$ \\
\hline & $\mathrm{MH}$ & $14.78 \%$ & $13.13 \%$ & $11.05 \%$ & $17.78 \%$ & $9.58 \%$ & $19.27 \%$ \\
\hline & $\mathrm{H}$ & $6.48 \%$ & $18.74 \%$ & $4.25 \%$ & $21.20 \%$ & $3.57 \%$ & $20.20 \%$ \\
\hline
\end{tabular}

${ }^{*} \mathrm{~L}=\mathrm{Low} ; \mathrm{ML}=$ Medium-low; $\mathrm{M}=$ Medium; $\mathrm{MH}=$ Medium-high; $\mathrm{H}=$ High; $\mathrm{T}=$ Total 
In Table 1, it is analyzed the forward participation, which represents the percentage of indirect domestic value-added - that is, the original domestic value that is incorporated in the exports from industrial sectors in other countries. In the Chinese case, the main indexes are in the sectors of high and medium-high technological intensity. In the Brazilian case, there is small forward participation. In this respect, the Brazilian domestic value incorporated in exports from other countries grew in the period analyzed, but less than the volume of gross exports, causing the country to present smaller forward participation in the GVCs.

In the backward participation, which represents the foreign value-added present in the exports of the analyzed country, in the Chinese economy, the highest percentage is found in high technological intensity, while in Brazil it is in low intensity. With this, if compared to Brazil, China, in addition to having greater participation in GVCs, also participates in sectors whose technological dynamism involves greater capital intensity and technological learning.

In addition to the insertion of the countries in GVCs, one can assess in which technological intensities Brazil and China have comparative advantages calculated in terms of domestic value-added. Doing so, both China and Brazil had relevant comparative advantages in sectors with lower technological dynamism, such as medium and medium-low; however, China also presents and maintains during the period advantages in sectors of high technological intensity.

Regarding gross exports, the sectors of medium-low technological intensity are the main responsible ones for Brazilian exports in 2005, while in China exports are mainly represented by high technological intensity. In 2015, Brazil deepened its dependence on sectors of medium-low and low technological intensity, while China maintained the importance of high technological intensity and a diversified basket. Finally, when comparing the participation of domestic value-added in exports in total annual exports to the breakdown of gross exports, one can observe that the percentages are lower for both Brazil and China, and that the largest discrepancies are concentrated in the Chinese sectors of high technological intensity.

In conclusion, there are quantitative differences (in terms of volume) regarding the participation of the two countries in GVCs, but also qualitative ones, captured by the sectoral breakdown by technological intensity. Thus, this justifies the importance of presenting an indicator $\left(q_{\text {tech }}\right)$ that explores the perspective of international insertion from two perspectives, the specialization of technological intensities and the relevance of these changes in terms weighted to the country's export volume.

\section{An analysis of changes in the technological sophistication index between 2005 and 2015}

This section aims to assess whether there was a recomposition of the pattern of Brazilian and Chinese specialization over the years 2005 to 2015, from the data on domestic value-added in exports. It begins by presenting in Figure 3 a summary of the results of $q_{\text {tech }}$ by sector and technological intensity in 2005 and in 2015, aiming to evaluate the process of reconfiguring the international insertion of the two 
countries in GVCs based on specialization and relevance. In the sequence, a synthesis of the process is presented, in order to evaluate the dynamic results.

Figure: 3: Index $\boldsymbol{q}_{\text {tech }}$ by technological intensity according to specialization and relevance for China and Brazil in 2005 and 2015
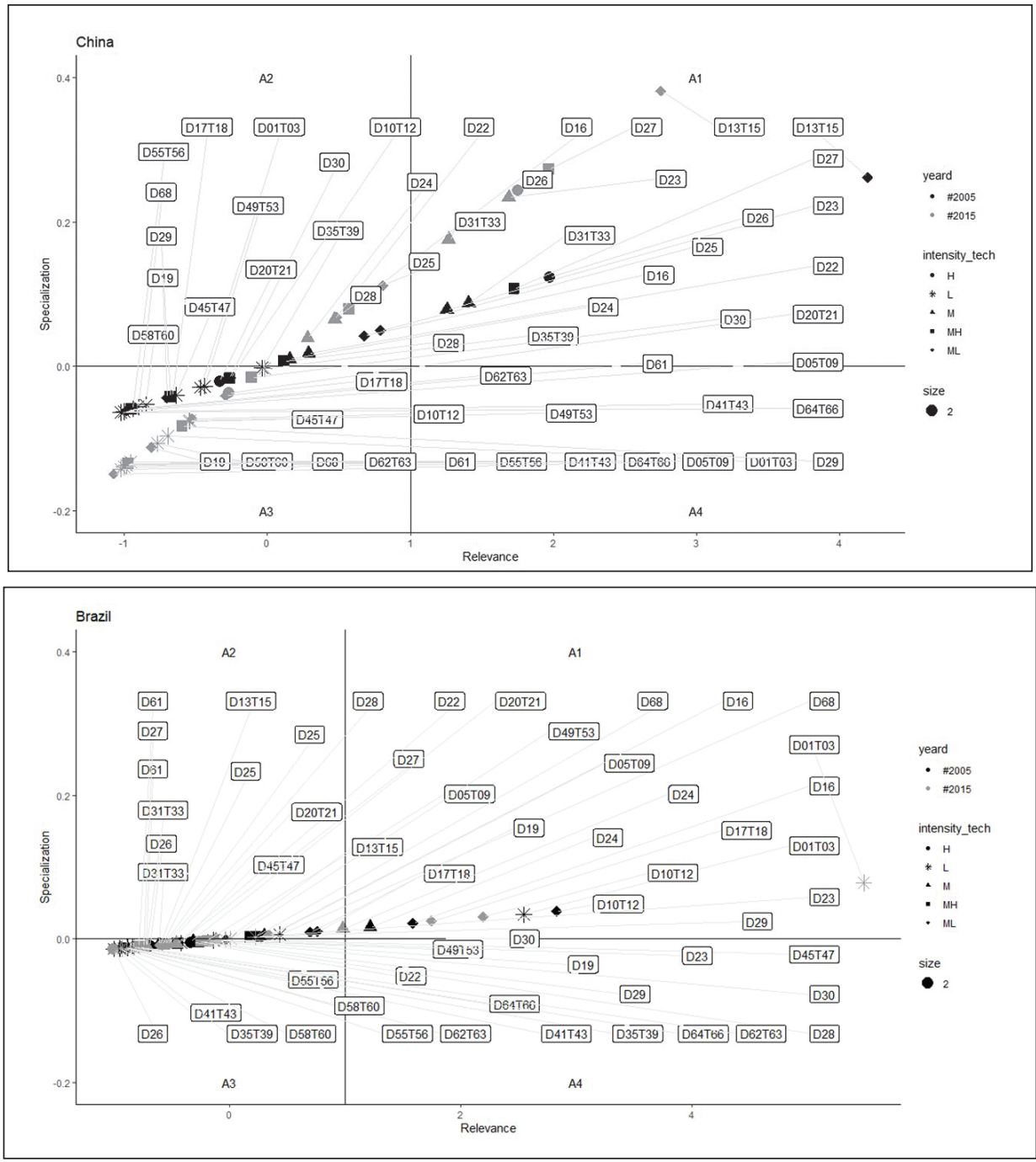

Notes: Quadrants: A1 - Specialized and relevant; A2 - Specialized and not very relevant; A3 - Non-specialized and not very relevant; $A 4$ - Non-specialized and not very relevant Tech_intensity: H: High; L: Low; A: Medium; MH: Medium-high; ML: Medium-low.

Source:" The sectors represented in the figures are qualified in terms of technological intensity, according to Galindo-Rueda and Verger (2016). The abbreviation names can be seen in Appendix 1.

Figure 3 categorizes the Brazilian and Chinese international insertion process in terms of $q_{\text {tech }}$. One can analyze the variations in the indicator for each sector, 
that is, for when $q_{\text {tech }}>0$, in which the sector becomes specialized, and $q_{\text {tech }}>|1|$, in which the sector becomes relevant.

In the Brazilian case, one can observe: i) the agriculture, forestry, and fishing sector doubled its relevance in the period; ii) the transport, storage, and mining services sector has become specialized; iii) the construction, wood, and wood and cork products and basic metals sectors are no longer relevant; iv) paper and printing products and computers, optical and electronic products sectors have become relevant; v) coke and refining products, other non-metallic minerals, motor vehicles, trailers and semi-trailers, other transport equipment sectors are no longer specialized. Furthermore, as can be seen, in quadrant A1 there are no sectors of medium-high and high technological intensity, and there was no recomposition in the analyzed period.

In the Chinese case, one can see relative stability in the positioning of the sectors regarding specialization and relevance. The few changes are i) the mining sector has become relevant; ii) the textile sector, although still specialized and relevant, had a variation of $q_{\text {tech }}$ from 4.2 in 2005 to 2.75 in 2015. In addition, there are sectors of high and medium-high technological intensity that compose and remain in quadrant A1 throughout the period.

In addition, one can analyze in static terms as shown in Figure 4. It shows the quadrants in which the sectors were in 2005 and in which they were in 2015.

Figure 4: Index $q_{\text {tech }}$ by industrial sectors and sector groupings by technological intensity (in parentheses) in 2005 and 2015

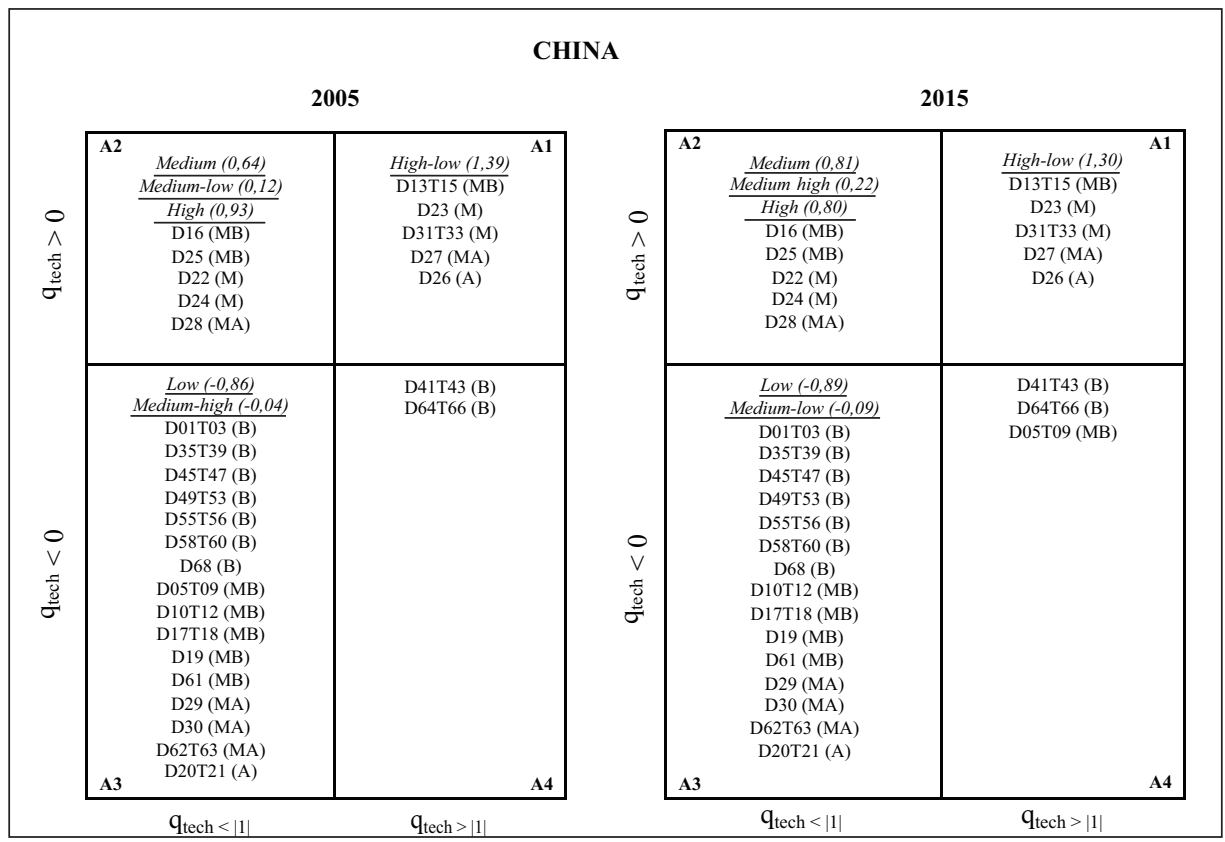




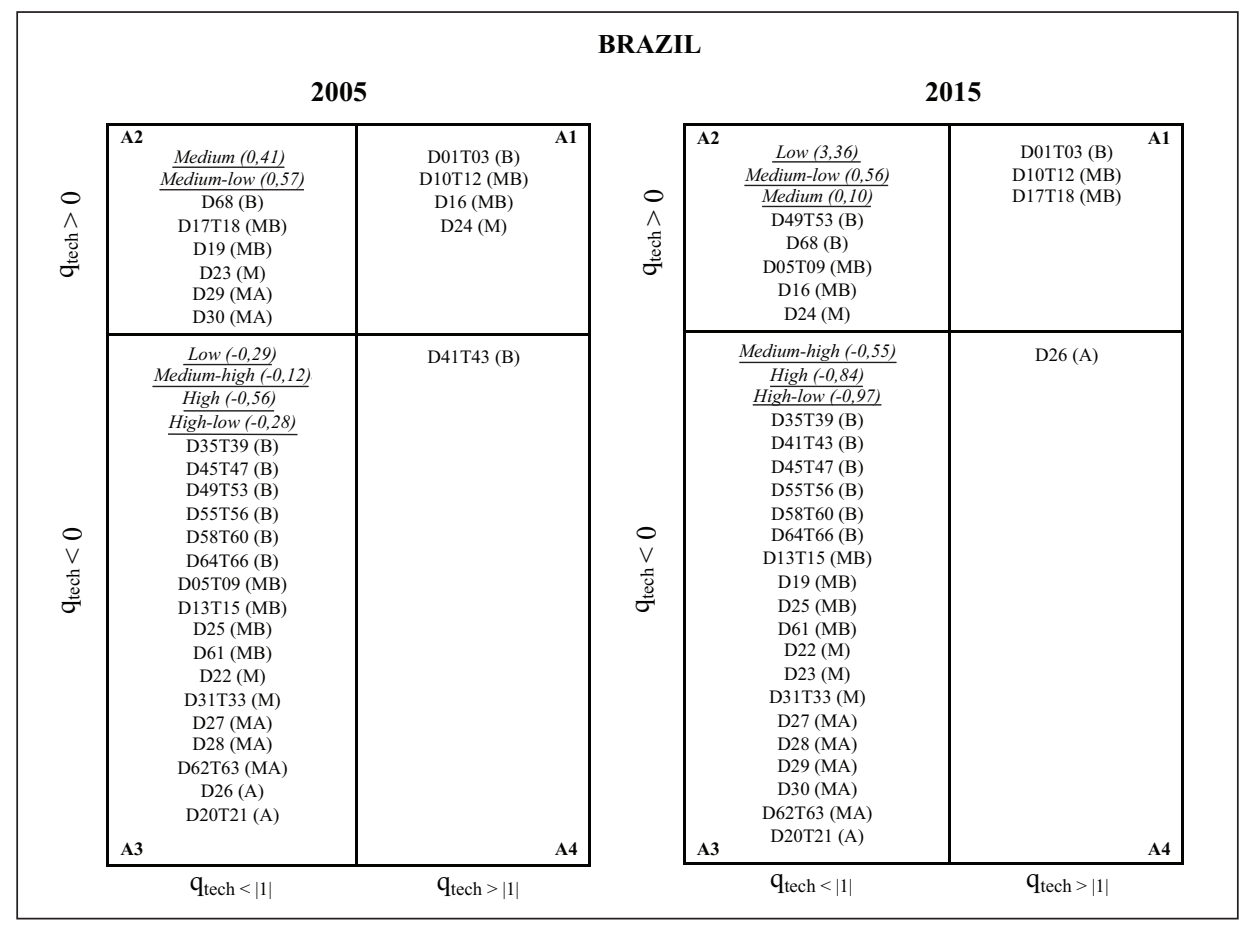

In the Brazilian case, it can observe that: i) the low technological intensity sectors became specialized from 2005 to 2015 , that is, they are sectors that increased the domestic value-added compared to the rest of the world and the other sectors of the Brazilian economy; ii) the high tech sectors, compared to those with low technological intensity, deepened their positioning, what means that they became more negative, showing the strength of the low-intensity sectors in the composition of the index. In the Chinese case, the following stand out: i) the medium-high technological intensity sectors have become specialized, stimulated mainly by the electrical equipment and machinery and equipment sectors; ii) the medium-low technological intensity sectors are no longer specialized. In addition, the index of high compared to low technological intensity maintained its position in quadrant A1.

Through this perspective, the data shows a low transformation in the international insertion, as there are no great variations in the sectors during the analyzed period. Considering that the time period evaluated involves an international crisis and a cooling in the international participation in GVCs by countries, as previously assessed, the little variability in the sectorial recomposition process seems to be contextually justified. Even so, considering the differences in the domestic valueadded in the countries' exports compared to the world, the proposed index allows evaluating the quality of the Brazilian international insertion compared to China. In this sense, the number of sectors of medium-high and high technological intensity in China and the index of high compared to low technological intensity present 
in quadrant A1 highlight the difference in Chinese presence in the international scenario compared to Brazilian.

Additionally, it is important to mention that even the proposed measurement for $q_{\text {tech }}$, showing some differences in relation to Hermida (2016), the results in this paper reinforce the ones found by the author. In assessing the relationship between the high and low technology sectors (q), the author found that Brazil was unable to make $q$ greater than zero between 1995 and 2011, while China did, consolidating a greater sophistication in its export.

\section{FINAL CONSIDERATIONS}

This study aimed to map and analyze the asymmetric patterns of integration in GVCs by Brazil and China's economies. To do so, the arguments started from the historical, theoretical, and empirical observation that the patterns of integration must be understood from two main conditions: (a) the domestic productive structure and (b) the national capacity to formulate industrial policies that promote a virtuous integration process that is associated with a permanent structural transformation towards more virtuous activities of the current productive paradigm. Thus, the analyses in this article are constructed from a counterpoint to the mainstream view that suggests a supposed automatism between integration and convergence.

Regarding the results, one can see that the countries are connected to GVCs with different specificities. That is, the Chinese economy maintained an advantage of participation in more dynamic sectors with higher levels of technological intensity. In the Brazilian case, there is a process of deepening the participation of sectors with less technological content. Concerning the proposed index and the theoretical debate on the importance of local policies, this research evaluates that the differences in the design of these policies have allowed the Asian economy to integrate with GVCs in sectoral groupings that have both comparative statistical and dynamic advantages. That is, policies seem to be one of the determinants of differences in the dynamics of the technological sophistication index.

It should be noted that, for reasons of scope and space, elements such as governance at CGVs and the importance of National Innovation Systems for determining integration standards were not explicitly analyzed, which limits the generalization of the results found from the logic of the proposed index. Furthermore, assessing integration patterns using $q_{\text {tech }}$ makes it possible to overcome some methodological limitations found in the literature, but does not include the implications of the transformations in the techno-productive paradigm (in the direction of what has been called Industry 4.0 and the organization of accumulation dynamics around technological platforms), since it goes beyond the effort of the article.

As a research agenda, it can be proposed expanding the evaluations regarding the countries in a qualitative - to analyze productive chains in all their stages - and quantitative perspective - to measure, at the product level, aspects related to the 
technology transfer in the GVCs to better support the formulation of industrial policies in the context of greater technological pervasiveness.

\section{REFERENCES}

AREND, M. (2015) A industrialização do Brasil ante a nova divisão internacional de trabalho. Presente e futuro do desenvolvimento brasileiro.

BUTOLLO, F. (2020) Digitalization and the geographies of production: Towards reshoring or global fragmentation? Competition and Change.

DAUDIN, G.; RIFFLART, C.; SCHWEISGUTH, D. (2011) Who produces for whom in the world economy? Canadian Journal of Economics, v. 44, n. 4, p. 1403-1437.

EUROPEAN UNION CHAMBER OF COMMERCE IN CHINA. (2017) China Manufacturing 2025. p. 64.

FEENSTRA, R. C.; HANSON, G. H. (1999) The impact of outsourcing and high-technology capital on wages: Estimates for the United States, 1979-1990. Quarterly Journal of Economics, v. 114, n. 3, p. 907-940.

FURTADO, A. T.; CARVALHO, R. Q. (2005) Padrões de intensidade tecnológica da indústria brasileira: um estudo comparativo com os países centrais. São Paulo em Perspectiva, v. 19, n. 1, p. 70-84.

GALINDO-RUEDA, F.; VERGER, F. (2016) OECD taxonomy of economic activities based on R\&D intensity. OECD Science, Technology and Industry Working Papers, v. 4, p. 24.

GEREFFI, G.; HUMPHREY, J.; STURGEON, T. (2005) The governance of global value chains. Review of International Political Economy, v. 12, n. 1, p. 78-104.

HAUSMANN, R.; HIDALGO, C. A. et al. (2017) The atlas of economic complexity: mapping paths to prosperity. v.54.

HAUSMANN, R.; HWANG, J.; RODRIK, D. (2006) What you export matters. Journal of Economic Growth, v. 12, n. 1, p. 1-25.

HERMIDA, C. C. (2016) Padrão de especialização comercial e crescimento econômico: uma análise sobre o Brasil no contexto da fragmentação da produção e das cadeias globais de valor. $\mathrm{PhD}$ Thesis. Federal University of Uberlandia (UFU). Uberlandia.

HUMMELS, D.; ISHII, J.; YI, K. M. (1999) The nature and growth of vertical specialization in world trade. Journal of International Economics. v. 54, n. 1, p. 75-96.

HUMMELS, D.; KLENOW, P. J. (2005) The variety and quality of a nation's exports. American Economic Review, v. 95, n. 3, p. 704-723.

KOOPMAN, R. et al. (2012) Give Credit Where Credit is Due: Tracing Value Added in Global Production Chains. SSRN Electronic Journal, n. 31.

KOOPMAN, R.; WANG, Z.; WEI, S. J. (2012) Tracing value-added and double counting in gross exports. Journal of Chemical Information and Modeling, v. 53, n. 9, p. 1689-1699.

LALL, S.; WEISS, J.; ZHANG, J. (2006) The "sophistication" of exports: A new trade measure. World Development, v. 34, n. 2, p. 222-237.

MARCATO, M. B. (2018) Trade integration in a vertically fragmented production structure: theory, metrics, and effects. PhD Thesis. Campinas State University.

MASIERO, G.; COELHO, D. B. (2014) A política industrial chinesa como determinante de sua estratégia going global. Revista de Economia Politica, v. 34, n. 1, p. 139-157.

NONNENBERG, M. J. B. (2014) Cadeias Globais de Valor e o desenvolvimento econômico. Boletim de Economia e Política Internacional, v. 18.

OECD (2018). Guide to OECD's Trade in Value Added (TiVA) Indicators, 2018 edition. n. December.

RODRIK, D. (2006) What's So Special About. Institute of World Economics and Politics, Chinese Academy of Social Sciences, v. 14. 
SARTI, F.; HIRATUKA, C. (2010) Indústria mundial: mudanças e tendências recentes. Texto para discussão. Instituto de Economia (IE/Unicamp). Campinas.

SARTI, F.; HIRATUKA, C. (2017) Desempenho recente da indústria brasileira no contexto de mudanças estruturais domésticas e globais. Para além da política econômica, p. 127-170.

SAVIOTTI, P. P. et al. (1982) An approach to the construction of indexes of technological change and of technological sophistication. The case of agricultural tractors. Technological Forecasting and Social Change, v. 21, n. 2, p. 133-147.

SCHOTT, P. K. (2004) Across-product versus within-product specialization in international trade. Quarterly Journal of Economics, p. 647-678.

TAGLIONI, D.; WINKLER, D. (2014) Making Global Value Chains Work for Development. n. 143.

TANG, M.; HUSSLER, C. (2011) Betting on indigenous innovation or relying on FDI: The Chinese strategy for catching-up. Technology in Society, v. 33, n. 1-2, p. 23-35.

TURCHI, L. M.; MORAIS, J. M. (2017) Políticas de apoio a inovação tecnológica no Brasil: avanços recentes, limitações e propostas de ações.

UNCTAD (2013) Measuring value in global value chain. Transnational Corporations.

\section{APPENDIX}

Appendix 1: Compatibility of TiVA sectors with the taxonomy of Galindo-Rueda and Verger (2016)

\begin{tabular}{|c|c|c|c|c|}
\hline & \multicolumn{2}{|c|}{ Galindo-Rueda and Verger (2016) } & \multicolumn{2}{|c|}{ TiVA (2018) } \\
\hline & Manufacture & Non-manufacture & Manufacture & Non-manufacture \\
\hline $\begin{array}{c}\text { High } \\
\text { intensity }\end{array}$ & $\begin{array}{l}\text { 21: Pharmaceutical } \\
\text { 26: Computers, } \\
\text { electronic and optical } \\
\text { products }\end{array}$ & 72: $P \& D$ & $\begin{array}{l}\text { D20T21: Chemicals and } \\
\text { pharmaceutical products } \\
\text { D26: Computers, } \\
\text { electronic and optical } \\
\text { products }\end{array}$ & \\
\hline $\begin{array}{l}\text { Medium- } \\
\text { high } \\
\text { intensity }\end{array}$ & $\begin{array}{l}\text { 30: Other transport } \\
\text { equipment } \\
\text { 29: Motor vehicle, } \\
\text { trailer, and semi-trailer } \\
\text { 28: Machinery and } \\
\text { equipment, nec } \\
\text { 20: Chemicals and } \\
\text { chemical products } \\
\text { 27: Electrical equipment }\end{array}$ & $\begin{array}{l}\text { 58: Publishing activity } \\
\text { 62-63: IT and other } \\
\text { information services }\end{array}$ & $\begin{array}{l}\text { D30: Other transport } \\
\text { equipment } \\
\text { D29: Motor vehicle, } \\
\text { trailer, and semi-trailer } \\
\text { D28: Machinery and } \\
\text { equipment, nec } \\
\text { D27: Electrical } \\
\text { equipment }\end{array}$ & $\begin{array}{l}\text { D62T63: IT and other } \\
\text { information services }\end{array}$ \\
\hline $\begin{array}{l}\text { Medium } \\
\text { intensity }\end{array}$ & $\begin{array}{l}\text { 22: Rubber and rubber } \\
\text { products } \\
\text { 23: Other non-metallic } \\
\text { mineral products } \\
\text { 24: Basic metals } \\
\text { 32: Other manufactures } \\
\text { 33: Repair and } \\
\text { installation of machinery } \\
\text { and equipment }\end{array}$ & & $\begin{array}{l}\text { D22: Rubber and rubber } \\
\text { products } \\
\text { D23: Other non-metallic } \\
\text { mineral products } \\
\text { D24: Basic metals } \\
\text { D31T33: Other } \\
\text { manufactures, repair and } \\
\text { installation of machinery } \\
\text { and equipment }\end{array}$ & \\
\hline
\end{tabular}




\begin{tabular}{|c|c|c|c|c|}
\hline $\begin{array}{c}\text { Medium-low } \\
\text { intensity }\end{array}$ & $\begin{array}{l}\text { 13: Textile } \\
\text { 15: Leather and related } \\
\text { products } \\
\text { 25: Metal products, } \\
\text { except machinery and } \\
\text { equipment } \\
\text { 17: Paper and other } \\
\text { paper products } \\
\text { 10-12: Food products, } \\
\text { beverages, and tobacco } \\
\text { 14: Clothing } \\
\text { 19: Coke and oil refining } \\
\text { 31: Furniture } \\
\text { 16: Wood and wood and } \\
\text { cork products } \\
\text { 18: Printing and } \\
\text { reproduction of } \\
\text { recorded media }\end{array}$ & 61: Telecommunication & $\begin{array}{l}\text { D13T15: Textile, } \\
\text { clothing, leather, and } \\
\text { related products } \\
\text { D05T09: Mining and } \\
\text { quarrying } \\
\text { D17T18: Paper products } \\
\text { and printing } \\
\text { D10T12: Food products, } \\
\text { beverages, and tobacco } \\
\text { D19: Coke and oil } \\
\text { refining } \\
\text { D16: Wood and wood } \\
\text { and cork products }\end{array}$ & $\begin{array}{l}\text { D25: Metal products } \\
\text { D61: Telecommunication } \\
\text { D05T09: Mining }\end{array}$ \\
\hline $\begin{array}{l}\text { Low } \\
\text { intensity }\end{array}$ & & $\begin{array}{l}\text { 64-66: Financial and } \\
\text { insurance activities } \\
\text { 35-39: Supply of } \\
\text { electricity, gas, and } \\
\text { water, waste } \\
\text { management and } \\
\text { remediation } \\
\text { 59-60: Audiovisual and } \\
\text { broadcasting activities } \\
\text { 45-47: Wholesale and } \\
\text { retail trade } \\
\text { 01-03: Agriculture, } \\
\text { forestry, and fishing } \\
\text { 41-43: Civil construction } \\
\text { 77-82: Administrative and } \\
\text { support services } \\
\text { 90-99: Arts, } \\
\text { entertainment, repair of } \\
\text { household items, and } \\
\text { other services } \\
\text { 49-53: Transport and } \\
\text { storage } \\
\text { 55-56: Accommodation } \\
\text { and food activities } \\
\text { 68: Real estate activities }\end{array}$ & & $\begin{array}{l}\text { D64T66: Financial and } \\
\text { insurance activities } \\
\text { D35T39: Supply of } \\
\text { electricity, gas, and water, } \\
\text { waste management and } \\
\text { remediation } \\
\text { D58T60: Editorial, } \\
\text { audiovisual, and } \\
\text { broadcasting activities } \\
\text { D45T47: Wholesale } \\
\text { and retail trade; } \\
\text { motor vehicle repair } \\
\text { D01T03: Agriculture, forestry, } \\
\text { and fishing } \\
\text { D41T43: Civil construction } \\
\text { D68: Real estate activities }\end{array}$ \\
\hline
\end{tabular}

